\title{
Development of Scale to Measure Knowledge of Farmers about Farmer Interest Group (FIG) under ATMA Project
}

\author{
Mugdha Ninama* and Arun Patel \\ Department of Extension Education, BACA, AAU, Anand, Gujarat, India \\ *Corresponding author
}

A B S T R A C T

Keywords

Knowledge about FIG, reliability, validity

\section{Article Info}

Accepted:

20 June 2021

Available Online:

10 July 2021
ATMA organize farmers into groups (FIGs and CIGs) and provided training, demonstrations and exposure visit on improved agricultural technologies and new agri-enterprises. Keeping this in view, to know the farmers' inclination towards FIG in terms of their knowledge, attitude and adoption an attempt has been made to develop a scale for measuring the knowledge of farmers about Farmer Interest Group under ATMA. Among the techniques available for the development of scale, a standardized technique chosen to develop a scale for the purpose. The item analysis used by Jha and Singh (1970) was carried out. The Biserial correlation for each item was calculated with the help of the formula suggested by Guilford (1965). The significance of the Biserial correlation coefficient was tested by using the formula given by Guilford (1965). The items found significant at 0.5 per cent level of significance was included in the final format of the knowledge test battery.

\section{Introduction}

Moreover, in this study highlighted Knowledge as those behaviours and test situations that emphasized the remembering either by recognition or recall of ideas, materials or phenomenon (Bloom et al., 1956). Knowledge is defined as body of information possessed by an individual. In this study knowledge is conceptualized as body of understood information possessed by FIG member farmer about FIG. Knowledge is one of the important components of behavior and as such plays an important role in the covert and overt behavior of an individual. Keeping the above definition in view, a standardized knowledge test was developed with the help of following technique. This can scientifically measure level of knowledge about FIG under ATMA project among member farmers. 


\section{Materials and Methods}

An attempt has been made in this study, to develop a scale, which can scientifically measure level of knowledge about Farmers Interest Groups under ATMA project among member farmers.

\section{Steps in development of knowledge test}

\section{Item collection}

The content of a knowledge test is composed of questions called items. Items for the test were collected from different sources, such as literature, field extension personnel, relevant specialists and the researchers own experience. The items were collected in relation to FIG. Care was taken to ensure that no crucial area should be left out. The collected items were discussed with ATMA officials and extension educationist for relevance of statements and for addition and alteration of the items. Keeping the following three criteria in view, the items were selected for the test:

The item should provide thinking rather than simply rote memorization.

The item should differentiate the well informed farmers from the poorly informed farmers and should have certain difficulty value.

The items included should cover all the areas of knowledge about Fig.

With this criteria in view, 48 items were initially selected for developing knowledge test.

\section{Item analysis}

The item analysis used by Jha and Singh (1970) was carried out so as to yield three kinds of information, viz., 'Index of item difficulty', 'Index of item discrimination' and 'Index of item validity'.

Index of item difficulty indicate that extent to which an item was difficult, while the index of item discrimination was calculated to find out whether an item really discriminates a wellinformed person from a poorly informed one.

The index of item validity provided the information on how well an item measures or discriminates in agreement with the rest of the test.

The items were administered to 42 respondents for item analysis. The respondents for administering the items were randomly selected and were not included in the sample for final study. This was done to avoid testing effect.

Each one of the 42 respondents, to whom the test was administered, was given a score 1 or 0 for each item, according to whether the answer was right or wrong. The total number of correct answers given by respondent out of collected items was the knowledge score of the individual. After calculating the score obtained by 42 respondents, the scores were arranged from highest to lowest in order of magnitude.

These 42 respondents were divided into six equal groups, each groups having ' 7 ' respondents and were arranged in descending order of total scores obtained by them. These groups were named as G1, G2, G3, G4, G5 and G6, respectively.

For item analysis, the middle two groups, i.e. G3 and G4 were eliminated. Only four extreme groups with high and low scores were considered for computation of item difficulty and item discrimination indices were as follows; 


\section{Calculation of Difficulty Index (Pi)}

The difficulty index of an item is defined as the proportion of respondents giving correct answer to that particular item. This was calculated by the following formula:

$\mathrm{Pi}=\times 100$

Where,

$\mathrm{Pi}=$ Difficulty index in percentage of the $\mathrm{i}^{\text {th }}$ item

ni $=$ Number of respondents giving correct answer to $i^{\text {th }}$ item

$\mathrm{Ni}=$ Total number of respondents

An example of calculation of Difficulty Index (Pi) of item no. 3 is presented below

$\mathrm{P}_{3}=\frac{\mathbf{n}_{\mathbf{i}}}{\mathbf{N}_{\mathbf{i}}} \times 100$

$\mathrm{P}_{3}=\frac{12}{28} \times 100$

$\mathrm{P} 3=42.85 \%$

Note

Range of $\mathrm{P}$ value for final selection of the item were 20 to 80 per cent as per the decided criteria by Jha and Singh (1970).

\section{Calculation of Discrimination Index $\left(E^{1 / 3}\right)$}

The discrimination index can be obtained by calculating the phi-coefficient as formulated by Perry and Michael (1951). However, Mehta (1958) in using $\mathrm{E}^{1 / 3}$ method to find out item discrimination emphasized that this method was analogous to, and hence, a convenient substitute for the phi-coefficient. The Discrimination Index $\left(\mathrm{E}^{1 / 3}\right)$ was used in the research study.
$\mathrm{E}^{1 / 3}=\frac{\left(\mathrm{s}_{1}+\mathrm{s}_{2}\right)-\left(\mathrm{s}_{5}+\mathrm{s}_{6}\right)}{\mathrm{N} / 3}$

Where,

$\mathrm{S}_{1}, \mathrm{~S}_{2}, \mathrm{~S}_{5}$ and $\mathrm{S}_{6}=$ The frequencies of correct answers in groups G1, G2, G5 and G6, respectively

$\mathrm{N}=$ Total number of respondents in the sample of item analysis.

An example of calculation of Discrimination Index $\left(E^{1 / 3}\right)$ of item no. 3is presented below

$\mathrm{E}^{113}=\frac{\left(\mathrm{s}_{\mathbf{1}}+\mathrm{s}_{\mathbf{2}}\right)-\left(\mathrm{S}_{\mathbf{5}}+\mathrm{S}_{\mathbf{6}}\right)}{\mathrm{N} / \mathbf{3}}$

$\mathrm{E}^{113}=\frac{(3+4)-(3+2)}{28 / 3}$

$\mathrm{E}^{113}=0.214$

\section{Note}

Range of $E^{113}$ values for final selection of the item were 0.21 to 0.79 as per the decided criteria by Jha and Singh (1970).

\section{Calculation of Biserial Correlation ( $r$ bis)}

It was used for the test item validation, when the criteria of validity are regarded as internal consistency that is, the relationship of total scores to a dichotomized response to any given item.

Keeping this in view, with the help of following formula suggested by Guilford (1965), the Biserial correlation for each item was calculated. The significance of the Biserial correlation coefficient was tested by using the formula given by Guilford (1965). The items found significant at 0.5 per cent 
level of significance was included in the final format of the knowledge test battery.

$$
\text { rbis }=\frac{M_{p}-M_{q}}{\sigma_{t}} \times \frac{p q}{y}
$$

Where,

$\mathrm{Mp}=$ Mean of $\mathrm{X}$ values for higher group and lower group (Giving correct answer of particular item) in dichotomized variable

$\mathrm{Mq}=$ Mean of $\mathrm{X}$ values for higher group and lower group (Giving wrong answer of particular item) in dichotomized variable

$\mathrm{P}=$ Proportion of cases in higher and lower group (Giving correct answer of particular item)

$\mathrm{q}=$ Proportion of cases in higher and lower group (Giving wrong answer of particular item)

$y=$ Ordinance of the unit normal distribution curve with surface equal to 1.0 at the point of division between segments containing $\mathrm{p}$ and $\mathrm{q}$ proportion of the cases.

$\sigma t=$ Standard deviation

An example of calculation of Biserial Correlation (rbis) of item no. 3 is presented below

ribs $=\frac{M_{p}-M_{q}}{\sigma_{t}} \times \frac{p q}{y}$

Where,

$\mathrm{P}=409$ [Summation of the scores obtained by 12 respondents passing the item (giving correct answer of item no. 3)]

$\mathrm{M}_{\mathrm{p}}=\frac{409}{12}=34.08($ Mean score $)$
Proportion $=\frac{12}{28}=0.43$

$q=509$ [Summation of the scores obtained by 16 respondents not passing the item (giving wrong answer of item no.3)]

$\mathrm{M}_{\mathrm{q}}=\frac{509}{16}=31.81$

Proportion $=\frac{16}{28}=0.57$

Hence,

$\frac{p q}{y}=0.6240[$ table value from Guilford 1965]

The proportion passing and failing are 0.57 and 0.43 respectively. The ' $y$ ' ordinate from table is 0.3928 [value of 0.57 in table value from Guilford (1965)]

$\frac{p q}{y}=\frac{0.43 \times 0.57}{0.3928}$

$\frac{p q}{y}=0.6240$

$\sigma_{\mathrm{t}}=$ (Standard deviation of the total items scores) $=4.13$

$r b i s=\frac{\mathbf{3 4 . 0 8}-\mathbf{3 1 . 8 1}}{\mathbf{4 . 1 3}} \times 0.6240$

rbis $=0.3431$

$r^{2} b i s=0.1177$

\section{Test of significance of rbis}

The coefficient of Biserial Correlation was tested for their significance by using the following formula as given by Guliford (1965). 
Table.1
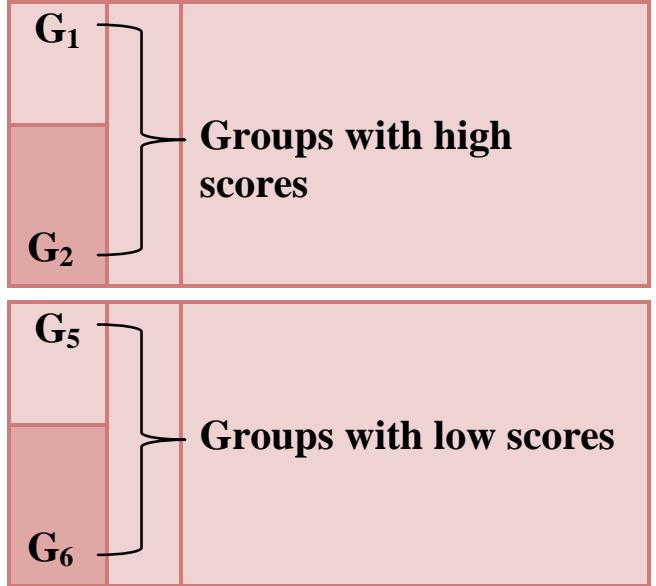

Table.2 Arrangement of the scores obtained by respondents from highest to lowest in order of magnitude

\begin{tabular}{|c|c|c|c|c|c|c|}
\hline \multirow{8}{*}{$\mathrm{G}_{1}$} & Sr. no. & Form no. & Scores & Sr. no. & Form no. & Scores \\
\hline & 1 & 1 & 45 & 8 & 10 & 36 \\
\hline & 2 & 15 & 42 & 9 & 12 & 36 \\
\hline & 3 & 06 & 39 & 10 & 22 & 36 \\
\hline & 4 & 09 & 39 & 11 & 04 & 35 \\
\hline & 5 & 13 & 38 & 12 & 02 & 35 \\
\hline & 6 & 14 & 36 & 13 & 11 & 35 \\
\hline & 7 & 16 & 36 & 14 & 30 & 35 \\
\hline \multirow{7}{*}{$\mathrm{G}_{3}$} & 15 & 31 & 35 & 22 & 27 & 34 \\
\hline & 16 & 38 & 35 & 23 & 45 & 34 \\
\hline & 17 & 41 & 34 & 24 & 03 & 33 \\
\hline & 18 & 20 & 34 & 25 & 08 & 33 \\
\hline & 19 & 39 & 34 & 26 & 21 & 33 \\
\hline & 20 & 40 & 34 & 27 & 25 & 33 \\
\hline & 21 & 24 & 34 & 28 & 33 & 33 \\
\hline \multirow{7}{*}{$\mathrm{G}_{5}$} & 29 & 35 & 33 & 36 & 34 & 32 \\
\hline & 30 & 36 & 33 & 37 & 26 & 32 \\
\hline & 31 & 42 & 32 & 38 & 29 & 31 \\
\hline & 32 & 44 & 32 & 39 & 05 & 31 \\
\hline & 33 & 17 & 32 & 40 & 23 & 30 \\
\hline & 34 & 18 & 32 & 41 & 28 & 30 \\
\hline & 35 & 32 & 32 & 42 & 19 & 29 \\
\hline
\end{tabular}


Table.3 Formation of six different groups of respondents by arranging them in descending order on the basis of scores obtained by them

\begin{tabular}{|c|c|c|}
\hline Group & $\begin{array}{c}\text { Serial no. of the } \\
\text { respondents in } \\
\text { descending order }\end{array}$ & $\begin{array}{c}\text { No. of } \\
\text { respondents }\end{array}$ \\
\hline $\mathbf{G}_{\mathbf{1}}$ & 1 to 7 & 7 \\
\hline $\mathbf{G}_{\mathbf{2}}$ & 8 to 14 & 7 \\
\hline $\mathbf{G}_{\mathbf{3}}$ & 15 to 21 & 7 \\
\hline $\mathbf{G}_{\mathbf{4}}$ & 22 to 28 & 7 \\
\hline $\mathbf{G}_{\mathbf{5}}$ & 29 to 35 & 7 \\
\hline $\mathbf{G}_{\mathbf{6}}$ & 36 to 42 & 7 \\
\hline
\end{tabular}

Table.4 Final four groups after elimination of middle two groups

\begin{tabular}{|c|c|c|}
\hline Group & $\begin{array}{c}\text { Serial no. of the } \\
\text { respondents in } \\
\text { descending order }\end{array}$ & $\begin{array}{c}\text { No. of } \\
\text { respondents }\end{array}$ \\
\hline $\mathbf{G}_{\mathbf{1}}$ & 1 to 7 & 7 \\
\hline $\mathbf{G}_{\mathbf{2}}$ & 8 to 14 & 7 \\
\hline $\mathbf{G}_{\mathbf{5}}$ & 29 to 35 & 7 \\
\hline $\mathbf{G}_{\mathbf{6}}$ & 36 to 42 & 7 \\
\hline
\end{tabular}

Table.5 Reliability of test to measure knowledge about Farmers Interest Group among member Farmers

\begin{tabular}{|c|c|c|c|c|c|c|}
\hline \multirow[t]{2}{*}{ No. } & $\begin{array}{c}\text { Score of Odd } \\
\text { Statement }\end{array}$ & $\begin{array}{l}\text { Score of Even } \\
\text { Statements }\end{array}$ & D & $d^{2}$ & $\mathbf{T}$ & $t^{2}$ \\
\hline & $\mathbf{X}_{\mathbf{0}}$ & $\mathbf{X}_{\mathbf{e}}$ & $\mathbf{X}_{\mathbf{0}}-\mathbf{X}_{\mathrm{e}}$ & $d \times d$ & $X_{0}+X_{e}$ & $t \times t$ \\
\hline 1 & 7 & 8 & -1 & 1 & 15 & 225 \\
\hline 2 & 10 & 8 & 2 & 4 & 18 & 324 \\
\hline 3 & 8 & 8 & 0 & 0 & 16 & 256 \\
\hline 4 & 11 & 9 & 2 & 4 & 20 & 400 \\
\hline 5 & 9 & 6 & 3 & 9 & 15 & 225 \\
\hline 6 & 9 & 8 & 1 & 1 & 17 & 289 \\
\hline 7 & 5 & 6 & -1 & 1 & 11 & 121 \\
\hline 8 & 10 & 9 & 1 & 1 & 19 & 361 \\
\hline 9 & 12 & 10 & 2 & 4 & 22 & 484 \\
\hline 10 & 12 & 10 & 2 & 4 & 22 & 484 \\
\hline 11 & 11 & 10 & 1 & 1 & 21 & 441 \\
\hline 12 & 8 & 9 & -1 & 1 & 17 & 289 \\
\hline 13 & 9 & 8 & 1 & 1 & 17 & 289 \\
\hline 14 & 11 & 12 & -1 & 1 & 23 & 529 \\
\hline 15 & 12 & 12 & 0 & 0 & 24 & 576 \\
\hline
\end{tabular}




\begin{tabular}{|c|c|c|c|c|c|c|}
\hline 16 & 7 & 9 & -2 & 4 & 16 & 256 \\
\hline 17 & 5 & 6 & -1 & 1 & 11 & 121 \\
\hline 18 & 6 & 6 & 0 & 0 & 12 & 144 \\
\hline 19 & 8 & 10 & -2 & 4 & 18 & 324 \\
\hline 20 & 8 & 9 & -1 & 1 & 17 & 289 \\
\hline 21 & 7 & 9 & -2 & 4 & 16 & 256 \\
\hline 22 & 11 & 10 & 1 & 1 & 21 & 441 \\
\hline 23 & 13 & 11 & 2 & 4 & 24 & 576 \\
\hline 24 & 10 & 9 & 1 & 1 & 19 & 361 \\
\hline 25 & 9 & 8 & 1 & 1 & 17 & 289 \\
\hline 26 & 11 & 9 & 2 & 4 & 20 & 400 \\
\hline 27 & 12 & 10 & 2 & 4 & 22 & 484 \\
\hline 28 & 13 & 12 & 1 & 1 & 25 & 625 \\
\hline 29 & 9 & 8 & 1 & 1 & 17 & 289 \\
\hline 30 & 11 & 9 & 2 & 4 & 20 & 400 \\
\hline Total & 284 & 268 & 16 & 68 & 552 & 10548 \\
\hline
\end{tabular}

Table.6 Final format for measure the level of knowledge of farmers' about Farmers Interest Group

\begin{tabular}{|c|c|c|c|c|}
\hline Sr.No. & \multicolumn{4}{|c|}{ Statement } \\
\hline 1. & \multicolumn{4}{|c|}{ Under which scheme Farmers Interest Group (FIG) is working? } \\
\hline & A) & \begin{tabular}{r|r} 
ATMA \\
\end{tabular} & B) & Kisan call centre \\
\hline & C) & National Food Security Mission & D) & Rashtriya Krishi VikasYojana \\
\hline \multirow[t]{3}{*}{2.} & \multicolumn{4}{|c|}{ Who does the registration of a Farmers Interest Group? } \\
\hline & A) & By Project Director of ATMAs & B) & By Mamlatdar \\
\hline & C) & By Sarpanch & D) & By the collector \\
\hline \multirow[t]{3}{*}{3.} & \multicolumn{4}{|c|}{ How much fees are there in Farmer Interest Group per member? } \\
\hline & A) & Rs. 10 & B) & Rs. 1000 \\
\hline & C) & Rs.500/- & D) & Rs.300/- \\
\hline \multirow[t]{3}{*}{4.} & \multicolumn{4}{|c|}{ What kind of members should be in the Farmers Interest Group? } \\
\hline & A) & At least one interest & B) & Members with a similar height \\
\hline & C) & They should be from the same family & D) & They should be employed \\
\hline \multirow[t]{3}{*}{5.} & \multicolumn{4}{|c|}{ Can a person have member in more than one Farmer Interest Group? } \\
\hline & A) & No & B) & Do not know \\
\hline & C) & Yes & D) & Neutral \\
\hline \multirow[t]{2}{*}{6.} & \multicolumn{4}{|c|}{ Why one member cannot participate in more than one Farmers Interest Group? } \\
\hline & A) & $\begin{array}{l}\text { Since members of the other group do } \\
\text { not like }\end{array}$ & B) & $\begin{array}{l}\text { Since the necessity of equality } \\
\text { and impartiality is essential }\end{array}$ \\
\hline
\end{tabular}




\begin{tabular}{|c|c|c|c|c|}
\hline & C) & $\begin{array}{l}\text { Since not enough attention is given to } \\
\text { each group }\end{array}$ & D) & $\begin{array}{c}\text { The crowed in the group so } \\
\text { that }\end{array}$ \\
\hline \multirow[t]{3}{*}{7.} & \multicolumn{4}{|c|}{ How many meetings should be held in a year by the farmers Group? } \\
\hline & A) & Twelve meetings & B) & 365 meetings \\
\hline & C) & 100 meetings & D) & No one \\
\hline \multirow[t]{3}{*}{8.} & \multicolumn{4}{|c|}{ In which programmes farmers can participate after joining this group? } \\
\hline & A) & $\begin{array}{c}\text { Training, Inspiration tour, } \\
\text { demonstration, farm school and } \\
\text { award etc. }\end{array}$ & B) & In the public programme \\
\hline & C) & In the social programmes & D) & In educational programmes \\
\hline \multirow[t]{3}{*}{9.} & \multicolumn{4}{|c|}{ What are the activities undertaken in Farmers Interest Group? } \\
\hline & A) & $\begin{array}{l}\text { Capacity Building, Skill Development } \\
\text { and Support Services }\end{array}$ & B) & Swimming and running \\
\hline & C) & Social service & D) & Service of the elders \\
\hline \multirow[t]{3}{*}{10.} & \multicolumn{4}{|c|}{ From whom you get the information about the Farmers Interest Group at the village level? } \\
\hline & A) & $\begin{array}{l}\text { Assistant technology Manager (ATM) } \\
\text { or farmer's friend }\end{array}$ & B) & $\begin{array}{c}\text { From the secretary of milk co- } \\
\text { operative society }\end{array}$ \\
\hline & C) & From the merchants of grain & D) & From the fertilizer shop \\
\hline \multirow[t]{3}{*}{11.} & \multicolumn{4}{|c|}{ Whom to contact for information about FIG at taluka level? } \\
\hline & A) & $\begin{array}{l}\text { Block Technology Manager (BTM) } \\
\text { or Subject Matter Specialist (SMS) }\end{array}$ & B) & Taluka member \\
\hline & C) & Mayor & D) & Taluka president \\
\hline \multirow[t]{3}{*}{12.} & \multicolumn{4}{|c|}{ What is the purpose of demonstrating the group of Farmers? } \\
\hline & A) & To increase the memory of the farmers & B) & $\begin{array}{l}\text { For the enjoyment of the } \\
\text { farmers }\end{array}$ \\
\hline & C) & $\begin{array}{l}\text { For direct guidance on whether new } \\
\text { research is beneficial to them or not }\end{array}$ & D) & $\begin{array}{l}\text { To increase the inspection } \\
\text { capability of the farmers }\end{array}$ \\
\hline \multirow[t]{3}{*}{13.} & \multicolumn{4}{|c|}{ For which purpose 'Kisan PrernaPravas’ (Exposure visit) is planned? } \\
\hline & A) & Pleasure trip & B) & $\begin{array}{l}\text { For farmers to know new } \\
\text { technology and adopt them on } \\
\text { their own farm }\end{array}$ \\
\hline & C) & To see new places & D) & For recreation \\
\hline \multirow[t]{3}{*}{14.} & \multicolumn{4}{|c|}{ Why do Krushi Mela/ exhibition are organized? } \\
\hline & A) & For farmers to meet each other & B) & For the pleasure of the farmers \\
\hline & C) & $\begin{array}{l}\text { For farmers to get the latest } \\
\text { information of new technology }\end{array}$ & D) & For travel \\
\hline \multirow[t]{2}{*}{15.} & \multicolumn{4}{|c|}{ Why farmer-scientist talk (Kisan Goshthi) is organized? } \\
\hline & A) & Farmers can know the scientific & B) & Give the benefits of the \\
\hline
\end{tabular}




\begin{tabular}{|c|c|c|c|c|}
\hline & & $\begin{array}{l}\text { researches and discuss issues related } \\
\text { to farming }\end{array}$ & & schemes \\
\hline & C) & To aware about farmer’s right & D) & $\begin{array}{l}\text { To determine the minimum } \\
\text { support price }\end{array}$ \\
\hline \multirow[t]{3}{*}{16.} & \multicolumn{4}{|c|}{ Who gets the best ATMA farmer award? } \\
\hline & A) & $\begin{array}{l}\text { Who participate in all activities of } \\
\text { ATMA }\end{array}$ & B) & $\begin{array}{l}\text { Who adopt new things from } \\
\text { their own resources and work } \\
\text { well on their own }\end{array}$ \\
\hline & C) & $\begin{array}{l}\text { Who have a good relationship with all } \\
\text { the farmers }\end{array}$ & D) & $\begin{array}{l}\text { Who cultivate all the types of } \\
\text { crop }\end{array}$ \\
\hline \multirow[t]{3}{*}{17.} & \multicolumn{4}{|c|}{$\begin{array}{l}\text { At the taluka level, at district level and at the state level, how many rupees are given for Best } \\
\text { ATMA farmer award? }\end{array}$} \\
\hline & A) & Rs. 10,000 & B) & \begin{tabular}{l|l} 
Rs. 5000 & \\
\end{tabular} \\
\hline & C) & Rs. 30000 & D) & Rs. 7000 \\
\hline \multirow[t]{3}{*}{18.} & \multicolumn{4}{|c|}{ At the district level how many rupees are given for Best ATMA farmer award? } \\
\hline & A) & Rs. 25,000 & B) & Rs. 5000 \\
\hline & C) & Rs. 3000 & D) & Rs. 7000 \\
\hline \multirow[t]{3}{*}{19.} & \multicolumn{4}{|c|}{ At the state level, how many rupees are given for Best ATMA farmer award? } \\
\hline & A) & Rs. 50,000 & B) & Rs. 5000 \\
\hline & C) & Rs. 3000 & D) & Rs. 7000 \\
\hline \multirow[t]{3}{*}{20.} & \multicolumn{4}{|c|}{ How many days does organizational training take? } \\
\hline & A) & 1 day or 2 days & B) & For one month \\
\hline & C) & For one year & D) & For six month \\
\hline \multirow[t]{3}{*}{21.} & \multicolumn{4}{|c|}{ Farmers' training is for how many maximum days? } \\
\hline & A) & 8 to 10 days & B) & For one month \\
\hline & C) & For one year & D) & For six month \\
\hline \multirow[t]{3}{*}{22.} & \multicolumn{4}{|c|}{ How many times and how many days are there for the educational tour inside state the state? } \\
\hline & A) & for 3 to 5 days & B) & for 7 days \\
\hline & C) & for 10 days & D) & for 30 days \\
\hline \multirow[t]{3}{*}{23.} & \multicolumn{4}{|c|}{ Who renew the membership of FIG? } \\
\hline & A) & Group leader & B) & Member himself \\
\hline & C) & Group members & D) & Sarpanch \\
\hline \multirow[t]{3}{*}{24.} & \multicolumn{4}{|c|}{ When the memberships of the Farmers Interest Group are renewed? } \\
\hline & A) & Every 3 year & B) & Every 5 year \\
\hline & C) & Every 10 years & D) & Every seven years \\
\hline 25. & & hat is the method for financial help giver & grou & by the ATMA to increase their \\
\hline
\end{tabular}




\begin{tabular}{|c|c|c|c|c|}
\hline & A) & Money-order & B) & Money bank \\
\hline & C) & Seed money & D) & Money loan \\
\hline 26. & \multicolumn{4}{|c|}{ In which bank you should have account, to get financial help given by ATMA? } \\
\hline & A) & Should be an account in any bank & B) & State Bank of India \\
\hline & C) & Bank of Baroda & D) & Co-operative bank \\
\hline \multirow[t]{3}{*}{27.} & \multicolumn{4}{|c|}{ How much money is given in SEED MONEY? } \\
\hline & A) & Ten thousand rupees & B) & One lack rupees \\
\hline & C) & Ten lack rupees & D) & Fifty thousand \\
\hline \multirow[t]{3}{*}{28.} & \multicolumn{4}{|c|}{ What does constituted by gathering more than one farmer's interest group? } \\
\hline & A) & Farmers Organization & B) & Coalition \\
\hline & C) & Groups & D) & Big Coalition \\
\hline
\end{tabular}

$\mathrm{t}=\frac{\frac{\text { rbis }}{\frac{\sqrt{p q}}{y}-r 2 b i s}}{\sqrt{\mathrm{N}}}$

$t=\frac{0.3431}{\frac{1.26-0.1177}{\sqrt{28}}}$

$\mathrm{t}=1.5891$ (Significant at 0.5 level of probability)

It means calculated value of ' $t$ ' is greater than table value (0.684) at 27 degree of freedom (n1 ) at 0.5 per cent level of significance. Thus, it is significant at 0.5 per cent level of significance and therefore item number 3 is selected.

\section{Representative of the test}

Though the aforesaid criteria were the main consideration for the final selection of the knowledge items, the cares were taken not to eliminate the important aspects if any. However, no one important item was left without selection.

\section{Reliability of the Test}

A test is reliable when it consistently produces the same results when it applied to the same sample. In the present study to test the reliability of the test, the split half method was used. The 30 statements were divided into two halves with 15 odd- numbered in one half and 15 even-numbered statements in the other.

These were administered to 30 respondents. Each of the two sets of statements was treated as a separate test and then these two sub-tests were correlated. The co-efficient of reliability was calculated by the Rulon's formula (Guilford, 1954), which came to 0.84 . However, reliability is directly related to the length of the test when we split to odd and even number items. The reliability coefficient which has been calculated is the value of half size of the original test. Thus, correction factor is calculated by using Spearman Brown formula. Which came to 0.91 .

Thus, the test developed was found highly reliable. To understand this procedure, we can examine the items for the test in Table 1.

\section{Rulon's Formula}

$\mathrm{rtt}=1-\frac{\sigma 2 d}{\sigma^{2} t}$

Where, 
$\sigma^{2} \mathrm{~d}=\frac{\sum \mathrm{d}^{2}-\frac{\left(\sum \mathbf{d}\right)^{2}}{\mathrm{~N}}}{\mathrm{~N}}$

$\sigma^{2} \mathrm{t}=\frac{\sum \mathrm{t}^{2}-\frac{\left(\sum \mathbf{d}\right)^{2}}{N}}{\mathrm{~N}}$

\section{Calculation}

$\sum d=16$

$\Sigma d^{2}=68$

$\mathrm{t}=552$

$\Sigma \mathrm{t}^{2}=10548$

$\mathrm{N}=30$

$\sigma^{2}=\frac{\sum d^{2}-\frac{\left(\sum d\right)^{2}}{30}}{30}$

$=\frac{68-\frac{(16)^{2}}{30}}{30}$

$=\frac{68-8.5333}{30}$

$=\frac{59.4667}{30}$

$\sigma^{2} \boldsymbol{d}=1.9822$

$\sigma^{2} \mathrm{t}=\frac{\sum \mathbf{t}^{2}-\frac{(\Sigma \mathrm{t})^{2}}{30}}{30}$

$=\frac{10548-\frac{(552)^{2}}{30}}{30}$

$=\frac{10548-\frac{304704}{30}}{30}$ $=\frac{10548-10156.8}{30}$

$=\frac{391.2}{30}$

$\sigma^{2} t=13.04$

$\mathrm{rtt}=1-\frac{\sigma^{2} d}{\sigma^{2} t}$

$=1-\frac{1.9822}{13.04}$

$\approx=0.84$

Correlation factor formula

$\mathrm{rtt}=\frac{2 \text { roe }}{1+\text { roe }}$

Where,

$\mathrm{rtt}=$ Coefficient of reliability of original test

roe $=$ Reliability of coefficient of odd and even score

$\mathrm{rrt}=\frac{2(0.84)}{1+0.84}$

$\mathrm{rrt}=0.91$

\section{Content validity of the test}

The Biserial correlation was considered as a measure of test item validity. Significant Biserial correlation coefficient proved the construct validity of the items included in the knowledge test battery.

\section{References}

Bloom, B. S., Engelhart, M. D.; Furst, E. J., Hill, W. H., Krathwohl,

D. 
R.(1956).Taxonomy of educational objectives: The classification of educational goals. Handbook I: Cognitive domain. New York: David McKay Company.

Guilford, J. P. (1965). Fundamental Statistics in psychology and education. New York : McGraw Hill Book Co. Inc., pp. 317-319.

Guliford, J. P. (1954).Psychometric Methods, Tata McGraw-Hill Publication Co. Ltd. Bombay, pp. 55-60.

Jha, P. N. and Singh, K. N. (1970).A test to measure farmer's knowledge about high yielding variety programme.Interdiscipline.7(1): 65-78.

Kerlinger, F. N. (1976) Foundation of Behavioural Research, Surjet Publication, New Delhi: 198-204.

Perry, N. C. and Michael, W. B. (1951) The estimation of a phi-coefficient for an entire criterion group from a phicoefficient calculated from the use of extreme tails of a normal distribution of criterion scores. Educational psychology Measurement,11:629-63.

\section{How to cite this article:}

Mugdha Ninama and Arun Patel. 2021. Development of Scale to Measure Knowledge of Farmers about Farmer Interest Group (FIG) under ATMA Project. Int.J.Curr.Microbiol.App.Sci. 10(07): 787-798. doi: https://doi.org/10.20546/ijcmas.2021.1007.086 